\title{
Income Inequality and Economic Growth: An Analysis Using a Panel Data
}

\author{
Mohamed Bouincha ${ }^{1} \&$ Mohamed Karim ${ }^{1}$ \\ ${ }^{1}$ EREMEFP, University of Mohammed V, Rabat, Morocco \\ Correspondence: Mohamed Karim, University of Mohammed V, Rabat, Morocco. Tel: 212-6618-3260. E-mail: \\ xmedkarimx@gmail.com
}

Received: February 13, 2018

Accepted: April 10, 2018

Online Published: April 25, 2018

doi:10.5539/ijef.v10n5p242

URL: https://doi.org/10.5539/ijef.v10n5p242

\begin{abstract}
A long time ago, economic growth was the main indicator of countries' economic health. However, since the 1970s, the analysis of the relationship between economic growth and other economic phenomena such as inequality has begun to grow (Sundrum, 1974). Much of the literature on the link between economic growth and income inequality is based on Kuznets revolutionary theory. The purpose of our article is to suspect the causality relationship between growth and inequality. To do this, we used data from 189 countries for the period between 1990 and 2015. We estimated a global model and three other of each category of countries in terms of development. In the global model, economic growth is insignificant even if its sign is positive. The same result appears in the developing country model and the moderately developed countries one. However, in the developed countries model, economic growth is negatively and statistically related to inequality. The Kuznets curve is approved in our study only when using human development indicator in the place of growth. Growth explain inequality's movement in our study only in the model of developed countries and its coefficient is negative.
\end{abstract}

Keywords: growth, inequality, GINI, panel data, human development indicator, GDP per capita

\section{Introduction}

Tackling the problem of income inequality is important because inequality hampers achievement of the Millennium Development Goals (MDGs) and poverty reduction efforts in general; it leads to an inefficient allocation of resources, a waste of production potential, a high rate of dependency and poor institutional development (Anyanwu, 2011). In addition, a recent study by the World Bank linked the Arab spring and the income distribution in the Arab region. Therefore, the analysis and monitoring of the evolution of inequalities is primordial for the continuity of economic activities in the sense that the social climate and political stability constitute pillars of economic prospection.

This is why several international organizations such as the World Bank and the OECD are giving more and more importance to the analysis of the issue of redistribution and poverty in the world. The objective of our study is to revisit the nature of the relationship between inequalities and growth. We will take advantage of the relative abundance of data related to the topic in recent years. We will analysis what extent the Kuznets theory applies in the case of a panel of several countries.

\section{Literature Review}

Most of the literature on the link between economic growth and income inequality is based on Kuznets' revolutionary theory. In his famous presidential address by the American Economic Association, published in 1955, examined the effect of economic growth on inequality. There are some patterns of growth in the economy that determine the trajectory of inequality. In particular, it postulates, in its famous inverted U-shaped curve, that structural transformation in the economy (which shifts resources from low-productivity sectors of the economy, such as agriculture, to sectors of higher productivity as industry and services) is associated with an increase in inequality (Kuznets, 1955). Later, when most people move to the most productive sectors, inequality will decline. Since then, several studies have tried to verify or negate the hypothesis.

Adelman and Morris (1973), in addition to the logarithm of GNP per capita and its square root, used several variables that represent the dynamics of the sample countries such as factor allocation across sectors, 
productivity gaps between sectors, distribution of wealth between households (GINI of land possessions), education, savings mobilized inside and outside. Other institutional and political variables were introduced in their model, such as the share of social expenditures, the share of public expenditures in GDP and initial conditions specific to each country, such as population and abundance of natural resources (Bathelemy, 1995).

In this article, Barthélemy has made a very fine analysis of the article by Kuznets. For him, the publication of Kuznets in 1955 is more of a quantitative analysis than an article of pure theory. He later explained the contributions and foundations, the strengths and limitations of the theory. Barthelemy presented several criticisms that economists have advanced on the Kuznets hypothesis by presenting several articles of study and the variables that each economist has added compared to that of Kuznets (Bathelemy, 1995).

Charles L. Wright, in his 1978 article, argued that Kuznets' theory is linked to the experience of a few European countries that have taken a big step in development and are not applicable in developing countries (Wright, 1978).

In the 90s, an interesting literature revisited this old question. Alesina and Rodrik (1994), Persson and Tabellini (1994), and Benabou (2000) looked in a different direction and constructed models of economic policy where the differences between the rich and the poor, in their political and voting decisions, can be bad for economic growth if there is more inequality.

Banerjee and Newman (1993) and Galor and Zeira (1993) focused on credit and investment constraints. This is linked to the idea of inequality of opportunity. For them, financial exclusion is a blatant picture of unequal opportunities. As such, Ferreira discussed in 2014 the relationship between growth and the inequality of opportunity, which for him must be distinguished from other types of inequality caused by the effort of each individual (Ferreira, Lakner, Lugo, \& Ozler, 2014).

Milanovic (1994) used the Gini coefficient as variables to explain the inequalities by a vector of variables composed of GDP per capita expressed in PPP of 1988, the ratio between the average income of the richest region and that of the poorest one, the percentage of employees working in the public sector to replace the old dummies for the former socialist countries. He also uses the share of social transfers in GDP to capture the social policy pursued by the various countries. His hypothesis is that there is a negative relationship between inequalities and social transfers.

Perseon and Tabellini has approved the negative relationship between growth and inequality using data from developed countries such as the United States and other developing countries (Persson \& Tabellini, 1994).

Birdsall, Ross, and Sabot (1995) worked on data from several East Asian countries that experienced rapid growth in the last decades of the 20th century. They found a positive causal effect of low inequality on economic growth and with low income inequality as an independent contributor to the rapid growth of East Asia. They concluded, therefore, that growth sharing policies can also stimulate growth. In particular, investment in education is the key to sustained growth, both because it contributes directly to productivity and because it reduces income inequality.

Roland BENABOU tried to explain why South Korea and the Philippines were in similar economic conditions in 1965, whereas in 1988, Korea made considerable progress in the Philippines. For him, it is the existing difference, already in 1965, in the distribution of income that has created the difference between the two tendencies. Subsequently, he presented the results of 24 studies that examine the relationship between inequality and growth (Benabou, 1996).

Alain de Janvry and Elisabeth Sadoulet used the data for the period 1970-1994 for 12 Latin and North American countries. They have shown that growth is effective in reducing poverty and inequality only if initial levels of inequality and poverty are not too high and education levels are high enough. They have shown that income growth following structural adjustment reforms is more effective at reducing poverty than income growth in the context of import substitution industrialization policies (De Janvry \& Sadoulet, 1996).

Klaus Deininger and Lyn Squire have used new transnational data on income and property distribution represented by the Land GINI to determine that there is a strong negative relationship between initial inequality in asset allocation and long-term growth. The study also shows that inequality reduces income growth for the poor, but not for the rich. The available longitudinal data provide little support for the Kuznets hypothesis. The study concluded that policies that increase overall investment and facilitate asset acquisition by the poor could be doubly beneficial for growth and poverty reduction (Deininger \& Squire, 1998).

In 2003, Adams analyzed the relationship between growth measured by per capita gross domestic product, inequalities measured by the Gini index and poverty measured by the square of the poverty gap. The study analyzed 101 observations from 50 developing countries. According to the study, growth is an important means 
of reducing poverty for developing countries. Indeed, economic growth reduces poverty because growth has little impact on inequality. In the data set, income inequality increases on average by less than $1.0 \%$ per year. Since income distribution is relatively stable over time, economic growth tends to increase the incomes of all members of society, including the poor (Adams Jr, 2003).

Ferreira, at a seminar organized by the services of the head of the Moroccan government, divided the timeline of the empirical literary on the relationship between inequalities and growth in three major phases. In phase 1, some key articles were written by Alesina and Rodrik (1994), Persson and Tabellini (1994) and Deininger and Squire (1998). They regress growth on initial inequality; they find a negative coefficient supporting the idea that initial inequality is bad for growth.

This changed in phase 2. New articles looked at country data as panel data and not as cross-sectional survey data. This approach reversed the results because they found positive coefficients. One possible explanation was that previous results of cross-sectional data had been biased downwards by the existence of omitted, time-invariant variables.

Finally, there was a third phase in the literature, which includes (Easterly, 2007) which finds that inequality, that he represented by agricultural allocations, hinders growth. (Berg, Ostry, \& Zettelmeyer, 2012) who observe how inequality reduces the duration of periods of high growth. (Ravallion, 2012) which explores the fact that initial poverty, rather than inequality, is negatively associated with economic growth. (Marrero \& Rodríguez, 2013) who find that when total income inequality is decomposed into inequality of effort and inequality of opportunity, it is negatively associated with subsequent growth. They turn the regressions with the two components of inequality and find that inequality of effort is positively linked to growth, but inequality of chances is negatively associated with him.

The OECD concluded in one of its recent studies published in 2014 that high levels of inequality have given rise to debates that are not about to be closed on the expected consequences for economic growth. On the one hand, it is argued that inequality could foster growth by, for example, encouraging economic agents to work, invest, take risks or increase their savings. On the other hand, it is argued that inequalities could affect growth, for example, by reducing equality of opportunity. Indeed, the poorest are discouraged to invest in training, thus penalizing the country's human capital and reducing the potential for growth. A third theory is that increased inequality leads to distortionary measures by disadvantaged populations, which affects the business climate (OECD, 2014).

\section{Method}

Through this article, we will, study the impact of growth on inequalities. We will estimate a global model for all countries and three other models of each group of countries according to the level of development. This choice is justified by the fact that the behavior of inequalities according to that of growth is different according to the degree of development of the country. On the other hand, the HDI is a composite indicator that encompasses education, health and per capita income; it is certainly going to be strongly correlated with several social-economic variables that the model may not include.

To do this, we built a large database using data for 189 countries over the period 1990-2015. Apart from those we calculated and the human development indicator, which is calculated in the database of UNDP (Note 1), all other variables come from the database of the World Bank (World Development Indicators (Note 2)).

According to the literature, there are several variables of an economic, socio-demographic and political nature that can explain the evolution of income inequalities. We have tried to integrate them into the overall model of our study, which is as follows:

$$
\text { GINI }_{i, t}=f\left(\text { GDP }_{i, t}, \text { Unem }_{i, t}, \text { Infl }_{i, t}, \text { HEM }_{i, t}, \text { Debt }_{i, t}, \text { Empl }_{i, t} \text { RurPop }_{i, t} \text { NatRes }_{i, t}, \text { Density }_{i, t}, \text { Agri }_{i, t}, \text { Health }_{i, t}\right)
$$

Where:

$$
\begin{aligned}
& \text { GINI = GINI index (World Bank estimate); } \\
& \text { GDP = GDP per capita constant } 2010 \text { USD; } \\
& \text { Unem = Unemployment total; } \\
& \text { Infl = Inflation (consumer prices); } \\
& \text { HEM = (Health expenditure on GDP + Education expenditure on GDP) / Military expenditure on GDP; } \\
& \text { Debt = Central government debt total on GDP; } \\
& \text { Empl = Employment to population ratio; }
\end{aligned}
$$


RurPop = Rural population of total population;

NatRes $=$ Total natural resources rents on GDP;

Density = Population density (people per $\mathrm{Km}^{2}$ );

Agri $=$ Agriculture value added per worker;

Health $=$ Health expenditure on GDP.

For the three models estimated for each development class. We relied on the HDI to classify the countries of our study into three classes. The first concerns developing countries, it contains the observations of the first third of the total interval. The second concerns the medium-developed countries and corresponds to the second third, while the third class relates to the developed countries represented by the highest third of the interval.

There are several types of models that can be estimated with panel data. However, the most common are Pooled Regression model, Fixed Effects model Random Effects model. To decide on the model to estimate, we performed the test Breusch -Pagan Lagrange multiply (LM) for random effects, the Hausman test to choice if using Fixed or Random effect model and the test of heteroscedasticity (Note 3). The Hausman test is a useful device for determining the specification of the common effects model. The other essential ingredient for the test is the covariance matrix of the difference vector $[b-\beta]$ (Greene, 2012).

\section{Results}

Before we start analyzing the results. It should be noted that there are countries that rely on consumption surveys to calculate the GINI index as Morocco and those that rely on income surveys as most OECD countries. At the economic level, it is clear that wealth inequalities are larger than income inequality and that income inequality is higher than spending inequality. Data on the wealth of individuals and households are generally not available and robust. Those concerning income are more used, especially in advanced countries. As in many developing countries, the lack of adequate data on incomes in Morocco means that economic inequalities are measured through household consumption expenditure.

\subsection{Evolution of Inequalities in the World}

The first finding that emerges from the data is that the majority of countries saw inequality decrease over the study period. Indeed, the distribution of income is determined as a result of the general equilibrium of the economy. Therefore, it is difficult to exactly identify the determinants of these movements. However, there are a few factors that the literature has highlighted. Figure 1 shows the evolution of the GINI index average for the period 2010-2015 in comparison with that of the period 1990-2000.

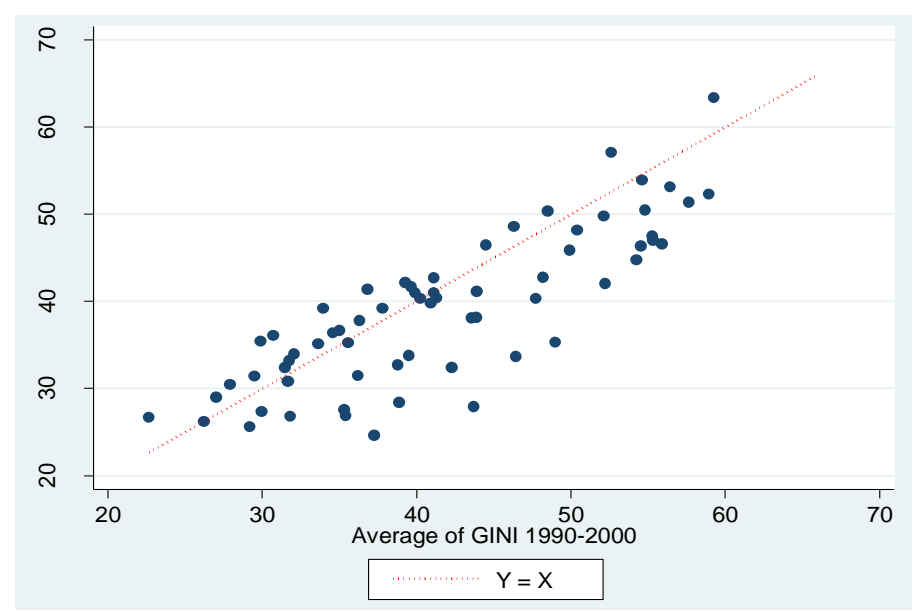

Figure 1. The evolution of the GINI indicator between 1990 and 2015

For (Ferreira, 2016), the decline in inequality between countries has been driven by globalization and the rise of industry in Asia. According to Richard Freeman of Harvard University, the entry of nearly 2 billion Asians into the labor force, for the production of goods that were not marketed twenty-five years ago, contributed to these changes in inequality. Recently, rising demand for commodities, both in China and elsewhere, has spawned benefits for commodity producers in Africa and Latin America. This super-cycle certainly contributed to stronger growth in these regions as well. 


\subsection{Inequalities and Social Problems}

It is obvious that inequalities have a negative effect on the socio-economic conditions of countries. The data in our study show a significant and negative correlation between the GINI index and the human development index. On the other hand, inequalities are positively correlated with the incidence of several social diseases and phenomena such as HIV, suicide, infant and neonatal mortality, incidence of tuberculosis and intentional homicides. Table 1 shows the correlation coefficients between the HDI and several social phenomena and some diseases that may have inequalities as a cause.

Table 1. The correlation between the GINI index and some social variables

\begin{tabular}{lccc}
\hline & Correlation of Pearson & Sig. (bilateral) & Number of observations \\
\hline Human Development Indicator &,$- 415^{* * *}$ & 0 & 1188 \\
Adolescents out of school, female &, $174^{* *}$ & 0 & 436 \\
Incidence of tuberculosis &, $280^{* *}$ & 0 & 971 \\
Incidence of malaria & $-0,05$ & 0,619 & 103 \\
Incidence of HIV &, $310^{* *}$ & 0 & 854 \\
Increase in poverty gap at $\$ 1.90$ &, $203^{* *}$ & 0 & 390 \\
Low birthweight babies &, $163^{*}$ & 0,017 & 211 \\
Maternal mortality ratio &, $241^{* *}$ & 0 & 293 \\
Mortality rate, infant &, $314^{* *}$ & 0 & 1213 \\
Mortality rate, neonatal &, $320^{* *}$ & 0 & 1213 \\
Smoking prevalence &,$- 334^{* *}$ & 0 & 246 \\
Suicide mortality rate &,$- 318^{* *}$ & 0 & 212 \\
\hline
\end{tabular}

Several social studies such as Gartner (1990) support a causal relationship between increased income inequalities (Cusson \& Boisvert, 1994). Indeed, an unequal redistribution of income normally creates social tensions between different segments of the population. And logically, violence in all its images such as homicides, theft, suicide increases putting authority to increase security spending at the expense of social services such as education and health. This process can bring the state into a vicious circle of violence and inequality without limit.
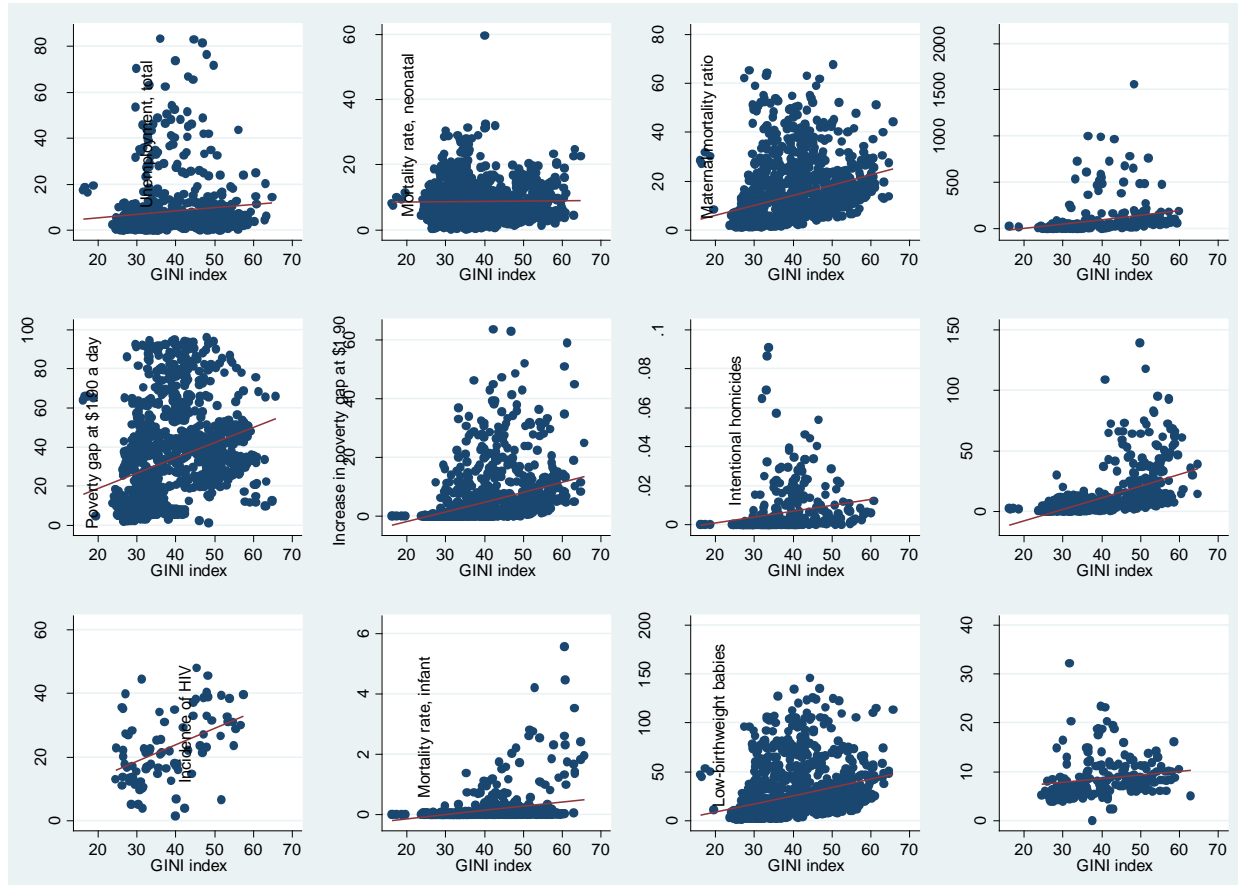

Figure 2. The GINI index and some socio-economic and socio-demographic variables

Figure 2 shows the relationship between the GINI index and the ratio of out-of-school children, the unemployment rate, the neonatal mortality rate, the maternal mortality ratio, vulnerable employment, the proportion of the population over- the poverty rate, the prevalence of intentional homicides, the share of 
companies reporting losses due to theft and vandalism, the incidence of HIV, the infant mortality rate, and the share of Newborns who suffer from underweight. Most variables are positively correlated with GINI. Indeed, the most unequal countries suffer more from social tensions, communicable diseases and the consumption of Drugs and alcohol. Disadvantaged groups use these products to compensate for hatred towards society and sometimes use violence against the rich as the last way to express their anger, thus increasing the level of societal violence.

\subsection{Inequality, Growth and Development}

The first finding that comes out of the data is the decrease in the level of inequality with the increase in per capita income. Figure 3 presents the distribution of the GINI index in relation to GDP per capita in constant $\$$ of 2010. There is a high concentration of observations in the low income bracket. This is due to the large number of countries with low per capita GDP in the world in addition to the countries experiencing the same problem before increasing per capita output in recent years such as China and some Gulf countries.

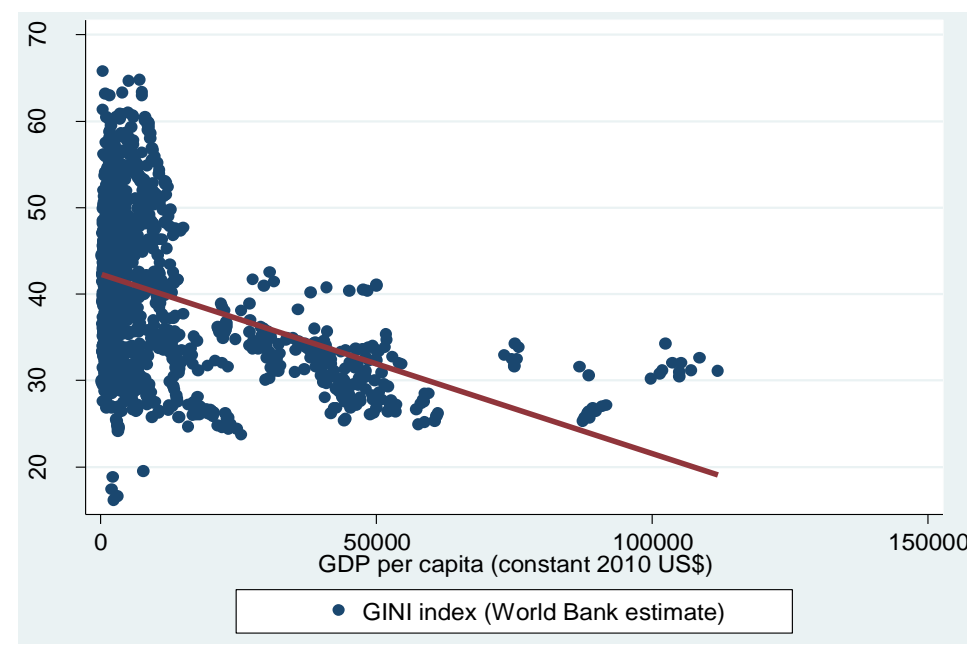

Figure 3. GINI index and GDP per capita across several countries

In general, the more the per capita income of a country increases, its distribution among the different social strata becomes more equitable. This is partly explained by the fact that the increase in income benefits the poor rather than the rich with the implementation of distributive policies with economic development. As proof, as shown in Table 2 below, the correlation coefficients between the GDP per capita and the GINI index differ according to the development class. Indeed, for the class of developing countries $(0,194 \leqslant \mathrm{HDI}<0,38275)$, the GDP per capita is not correlated with the index of GINI even if the coefficient is positive. This is due to the large number and heterogeneity of developing countries. Indeed, in this category, there are countries that are very poor in which poverty affects the whole population and therefore the distribution imbalance is low like the ones like the countries of the small islands, as there are big countries that are developing countries with huge natural resources but benefiting a minority of the population and therefore with a large distribution imbalance.

Table 2. The coefficient of correlation between the GINI index and the GDP per capita according to the development class

\begin{tabular}{cll}
\hline Coefficient of correlation & GINI index & for \\
\hline & $0.1842(0.2683)$ & Developing countries \\
GDP per capita & $0.4331^{*}(0.0000)$ & Medium lower development countries \\
(constant 2010 US \$) & $0.2956^{*}(0.0000)$ & Medium upper development countries \\
& $-0.3532 *(0.0000)$ & Developed countries \\
\hline
\end{tabular}

Countries with average development that is lower or higher $(0.38275 \leq \mathrm{HDI}<0.76025)$ are characterized by inequalities in a positive correlation with per capita income. These countries put in place economic policies to increase the national production but they benefit in the first place the favored classes because they still hold the large part of the means of production. The best example of this class is Morocco and most MENA countries, these countries are characterized by high levels of inequalities of access to finance, land inequalities and inequalities of wealth. 
It is at a higher level of development (HDI> 0.76025) that the correlation between GDP per capita and the GINI index becomes negative and statistically significant. To reach this stage, countries must put in place distribution rules that make it possible for society to benefit from the fruits of growth. The example of the developed countries is the Nordic countries. The setting of their tax, education, health and social protection systems enables them to reduce or even eliminate the inequalities of opportunity.

Figure 4 below shows the distribution of the GINI index as a function of the human development index. The distribution of the observations exactly follows the inverted U shape of Kuznets. We can therefore conclude that Kuznets' theory applies exactly except that the level of development of countries must be considered instead of economic growth.

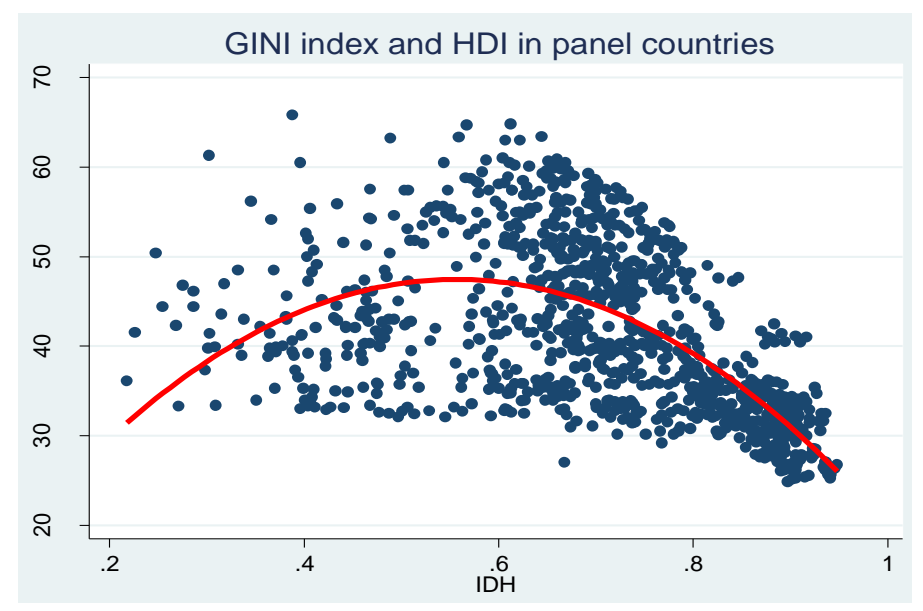

Figure 4. Inequalities and human development

In principle, developing countries are experiencing high levels of inequality. In addition, most countries give importance to the issues of growth and unemployment as means to develop before tackling the issue of the distribution of the fruits of growth. Therefore, inequalities increase for developing countries and those moderately developed. It is arriving at an advanced stage of development that countries are implementing their redistributive mechanisms to reduce inequality while increasing the wealth produced.

\subsection{Econometric Results}

The first analysis of the data indicates that much of the variance in the variables is due to differences between countries and a small share of variations in the same countries over the years of the study (Note 4). This is due to the large number of countries in the panel (189 countries) and their heterogeneity despite our study covering a relatively long duration (25 years).

The tests carried out show that our method of estimation should be as random effects model with heteroscedasticity presence and absence of autocorrelation. Indeed, the test result Breusch -Pagan Lagrange multiply (LM) obliges us not to use an OLS model and testing of hausman forces us to use a Random effect model and not a fixed model effects. Wald test indicates the presence of the heteroscedasticity in the model (Note 5). Therefore, we felt a Random effect robust model. 


\begin{tabular}{|c|c|c|c|c|}
\hline \multirow{2}{*}{$\begin{array}{c}\text { Dependent variable : GINI index } \\
\text { (World Bank estimate) }\end{array}$} & \multicolumn{4}{|c|}{ Models } \\
\hline & All countries & Developing countries & Medium development & Developed countries \\
\hline GDP per capita constant 2010 USD & $\begin{array}{l}0.0000458 \\
(0.72)\end{array}$ & $\begin{array}{c}0.00633 \\
(1.06)\end{array}$ & $\begin{array}{c}0.000699 \\
(0.93)\end{array}$ & $\begin{array}{c}-0.0000793 * \\
(-2.12)\end{array}$ \\
\hline Unemployment total & $\begin{array}{c}0.0970 * \\
(1.99)\end{array}$ & $\begin{array}{l}-0.126 \\
(-0.46)\end{array}$ & $\begin{array}{l}0.229^{*} \\
(2.20)\end{array}$ & $\begin{array}{l}0.145 * * * \\
(5.04)\end{array}$ \\
\hline Inflation (consumer prices) & $\begin{array}{l}-0.0230 \\
(-0.90)\end{array}$ & & & \\
\hline $\begin{array}{c}(\text { Health }+ \text { Education }) / \text { Military } \\
\text { expenditure }\end{array}$ & $\begin{array}{c}-0.181 * * * \\
(-5.15)\end{array}$ & & $\begin{array}{c}-0.238^{*} \\
(-2.46)\end{array}$ & $\begin{array}{c}-0.127 * * * \\
(-3.37)\end{array}$ \\
\hline Central government debt total & $\begin{array}{l}0.0148 * * \\
(3.22)\end{array}$ & & & \\
\hline Employment to population ratio & $\begin{array}{l}-0.0291 \\
(-0.78)\end{array}$ & & & \\
\hline Rural population of total population & $\begin{array}{l}0.260 * * * \\
(5.05)\end{array}$ & $\begin{array}{r}0.149 \\
(0.66)\end{array}$ & $\begin{array}{l}-0.0792 \\
(-0.77)\end{array}$ & $\begin{array}{c}0.165^{* *} \\
(3.29)\end{array}$ \\
\hline Total natural resources rents & $\begin{array}{l}0.179 \\
(1.96)\end{array}$ & & & \\
\hline Population density (people per $\mathrm{Km}^{2}$ ) & $\begin{array}{l}0.0260 * * \\
(2.88)\end{array}$ & & & \\
\hline Agriculture value added per worker & $\begin{array}{c}0.0000321 \\
(0.78)\end{array}$ & $\begin{array}{c}0.00203 \\
(0.71)\end{array}$ & $\begin{array}{c}-0.00105 \\
(-1.78)\end{array}$ & $\begin{array}{l}0.00000665 \\
\quad(0.57)\end{array}$ \\
\hline Health expenditure on GDP & & $\begin{array}{l}-0.200 \\
(-1.76)\end{array}$ & & \\
\hline Constant & $\begin{array}{l}33.98 * * * \\
(9.18)\end{array}$ & $\begin{array}{l}30.44 \\
(1.72)\end{array}$ & $\begin{array}{c}46.44 * * * \\
(6.96)\end{array}$ & $\begin{array}{c}32.56^{* * * *} \\
(14.51)\end{array}$ \\
\hline Observations & 217 & 21 & 180 & 450 \\
\hline
\end{tabular}

The model results confirm our analysis charts. Indeed, growth reduces inequality unless proper redistribution mechanisms are in place to know the model of developed countries in our study. In the global template (all countries), although its coefficient is positive, growth does not explain changes in inequality with a p-value of 0.471 , so economic growth should not be included in the model of inequality.

By cons in the model of developed countries, an increase in the growth of a percentage point can reduce inequalities with -0.0000793 units. For both models of moderately developed countries and developing countries, the growth rates are positive but not significant statistically.

According to the global model, the evolution of inequalities depends, among other things, the unemployment rate, the rate of the central government into debt, the rural population share in the total population on the density of the population, and the ratio between the amount of public spending on education and health of military expenditures. An increase in the unemployment rate with a percentage point increases income inequality with 0.0970 unit. For cons, the more the state invests a point of GDP in education and health at the expense of military loads, more inequality decrease of $-0,181$ unit. An increase in population density (persons per $\mathrm{km} 2$ area) increases inequality 0.0260 unit. Indeed, more people live in an area increasingly limited, income inequality increased. In addition, an increase in the share of rural population in the total population with a percentage point, more than the income inequality increases with 0.260 units.

The coefficients of the inflation, the total natural resources rents and the agriculture value added per worker positive are in the model purpose They Are not statistically significant. The same thing for the employment to population ratio but their coefficients is negatives. Those results affirmed the economic literature and logic.

\section{Conclusion}

The growth reduces inequality just if the country has reached an advanced level of development. The results of our study show that the condition sine qua non for growth reduces inequality is the implementation of redistributive mechanisms that aim to benefit all strata of the fruits of growth. Growth was negatively correlated e with inequality but the relationship is positive for developing countries and the moderately developed countries.

The Lorenz curve established a U-shaped relationship between growth and reverse the inequalities but our study is that we must consider the level of development instead of growth. This assertion has yet to develop in depth through an analysis of the long-term relationship between the two variables. 


\section{References}

Adams Jr, R. H. (2003). Economic growth, inequality, and poverty: Findings from a new data set. Retrieved from https://papers.ssrn.com/sol3/papers.cfm?abstract_id=1357182

Alesina, A., \& Rodrik, D. (1994). Distributive Politics and Economic Growth. The Quarterly Journal of Economics, 109(2), 465-490. https://doi.org/10.2307/2118470

Anyanwu, J. C. (2011). International remittances and income inequality in Africa. Review of Economic and Business Studies, 7(5), 117-148.

Banerjee, A. V., \& Newman, A. F. (1993). Occupational choice and the process of development. Journal of Political Economy, 101(2), 274-298. https://doi.org/10.1086/261876

Bathelemy, philippe. (1995). l'hypothèse de Kuznets est-elle encore d'actualité? Revue Région \& Développement, (2).

Benabou, R. (1996). Inequality and growth. NBER Macroeconomics Annual, 11, 11-74. https://doi.org/10.1086/654291

Benabou, R. (2000). Unequal societies: Income distribution and the social contract. American Economic Review, 96-129. https://doi.org/10.1257/aer.90.1.96

Berg, A., Ostry, J. D., \& Zettelmeyer, J. (2012). What makes growth sustained? Journal of Development Economics, 98(2), 149-166. https://doi.org/10.1016/j.jdeveco.2011.08.002

Birdsall, N., Ross, D., \& Sabot, R. (1995). Inequality and growth reconsidered: lessons from East Asia. The World Bank Economic Review, 9(3), 477-508. https://doi.org/10.1093/wber/9.3.477

Cusson, M., \& Boisvert, R. (1994). L'homicide conjugal à Montréal, ses raisons, ses conditions et son déroulement. Criminologie, 27(2), 165-183. https://doi.org/10.7202/017359ar

De Janvry, A., \& Sadoulet, E. (1996). Growth, poverty, and inequality in Latin America: A causal analysis, 1970-94. Review of Income and Wealth. Retrieved from https://www.researchgate.net/publication/4727847_Growth_poverty_and_inequality_in_Latin_America_A_ causal_analysis_1970-94

Deininger, K., \& Squire, L. (1998). New ways of looking at old issues: inequality and growth. Journal of Development Economics, 57(2), 259-287. https://doi.org/10.1016/S0304-3878(98)00099-6

Easterly, W. (2007). Inequality does cause underdevelopment: Insights from a new instrument. Journal of Development Economics, 84(2), 755-776. https://doi.org/10.1016/j.jdeveco.2006.11.002

Ferreira, F. H. (2016). Inégalité de revenu et inégalité d'opportunité : évolution récente et relations (pp. 18-35). Presented at the La problématique des inégalités: Un enjeu crucial pour le développement du Maroc, Rabat Morroco.

Ferreira, F. H., Lakner, C., Lugo, M. A., \& Ozler, B. (2014). Inequality of opportunity and economic growth: A cross-country analysis. https://doi.org/10.1596/1813-9450-6915

Galor, O., \& Zeira, J. (1993). Income distribution and macroeconomics. The Review of Economic Studies, 60(1), 35-52. https://doi.org/10.2307/2297811

Greene, W. H. (2012). Econometric analysis.

Kuznets, S. (1955). Economic growth and income inequality. The American Economic Review, 1-28.

Marrero, G. A., \& Rodríguez, J. G. (2013). Inequality of opportunity and growth. Journal of Development Economics, 104, 107-122. https://doi.org/10.1016/j.jdeveco.2013.05.004

Milanovic, B. (1994). The Gini-Type Functions: An Alternative Derivation. Bulletin of Economic Research, 46(1), 81-90. https://doi.org/10.1111/j.1467-8586.1994.tb00580.x

OECD. (2014). Does income inequality hurt economic growth? FOCUS on Inequality and Growth.

Park, H. M. (2011). Practical guides to panel data modeling: A step-by-step analysis using stata. Public Management and Policy Analysis Program, Graduate School of International Relations, International University of Japan.

Persson, T., \& Tabellini, G. (1994). Is inequality harmful for growth? The American Economic Review, 600-621.

Ravallion, M. (2012). Why don't we see poverty convergence? The American Economic Review, 102(1), 
504-523. https://doi.org/10.1257/aer.102.1.504

Sundrum, R. M. S. (1974). Aspects of Economic Inequality in Developing Countries. The Bangladesh Economic Review, 2(1), 445-468.

Wright, C. L. (1978). Income inequality and economic growth: examining the evidence. The Journal of Developing Areas, 13(1), 49-66.

\section{Notes}

Note 1. UNDP: United Nations Development Program, http://hdr.undp.org/en/data

Note 2. See: http://databank.worldbank.org/data/reports.aspx?source=world-development-indicators;

Note 3. See (Park, 2011) for more information about tests and models to use.

Note 4. Appendix A presents the details on the decomposition of the variations of the variables;

Note 5. For more information on test results, see Appendix B, C and D.

\section{Appendix A. Descriptive analysis of model variables}

\begin{tabular}{|c|c|c|c|c|c|c|c|c|}
\hline \multicolumn{2}{|l|}{ Variable } & \multirow{2}{*}{$\begin{array}{l}\text { Mean } \\
94.5\end{array}$} & \multirow{2}{*}{$\begin{array}{l}\text { Std. Dev. } \\
54.27571\end{array}$} & \multirow{2}{*}{$\frac{\operatorname{Min}}{1}$} & \multirow{2}{*}{$\frac{\operatorname{Max}}{188}$} & \multicolumn{3}{|c|}{ Observations } \\
\hline Country & overall & & & & & & $\mathrm{J}=$ & 4888 \\
\hline & between & & 54.41507 & 1 & 188 & & $2=$ & 188 \\
\hline & within & & 0 & 94.5 & 94.5 & $\mathrm{~T}$ & $=$ & 26 \\
\hline \multirow[t]{3}{*}{ Year } & overall & 2002.5 & 7.500767 & 1990 & 2015 & & $\mathrm{~J}=$ & 4888 \\
\hline & between & & 0 & 2002.5 & 2002.5 & & $2=$ & 188 \\
\hline & within & & 7.500767 & 1990 & 2015 & & $=$ & 26 \\
\hline \multirow[t]{3}{*}{ GINI_i $\sim \mathrm{V}$} & overall & 39.4676 & 9.712197 & 16.2 & 65.8 & & $\mathrm{~J}=$ & 1213 \\
\hline & between & & 8.442046 & 24.57143 & 62.15 & & $2=$ & 161 \\
\hline & within & & 2.91564 & 28.31497 & 60.37316 & T-bar & $f=7$ & 53416 \\
\hline \multirow[t]{3}{*}{ GDP_pe $\sim \mathrm{A}$} & overall & 11300.61 & 16756.35 & 115.7941 & 141165.1 & & $\mathrm{~J}=$ & 4679 \\
\hline & between & & 18956.83 & 249.1907 & 141165.1 & & $2=$ & 187 \\
\hline & within & & 2879.062 & -14898.9 & 36423.18 & T-bar & $f=2$ & .0214 \\
\hline \multirow[t]{3}{*}{ Une $\sim$ LNE $Z$} & overall & 8.789268 & 6.32406 & 0 & 59.5 & & $\mathrm{~J}=$ & 2814 \\
\hline & between & & 7.120186 & .3461539 & 59 & & $2=$ & 181 \\
\hline & within & & 3.150472 & -7.774368 & 24.46199 & T-bar & $6=$ & 5.547 \\
\hline \multirow[t]{3}{*}{ Inflat $\sim$} & overall & 38.75394 & 574.5722 & -35.83668 & 24411.03 & & $\mathrm{~J}=$ & 4275 \\
\hline & between & & 149.4665 & .4780589 & 1445.803 & $\mathrm{n}$ & $2=$ & 176 \\
\hline & within & & 554.996 & -1405.416 & 23320.97 & T-bar & $f=2$ & .2898 \\
\hline \multirow[t]{3}{*}{ Heal th $\sim p$} & overall & 6.543331 & 7.169523 & .1347786 & 121.0703 & & $\mathrm{~J}=$ & 1811 \\
\hline & between & & 9.294592 & .1993646 & 101.7601 & & $=$ & 154 \\
\hline & within & & 2.089144 & -10.22805 & 25.85349 & $\mathrm{~T}$ & $=1$ & .7597 \\
\hline \multirow[t]{3}{*}{ Centra G } & overall & 53.68661 & 37.79083 & 0 & 289.8447 & & $=$ & 1359 \\
\hline & between & & 36.40473 & 0 & 182.2362 & $\mathrm{n}$ & $=$ & 108 \\
\hline & within & & 21.06539 & -88.07906 & 227.662 & T-bar & $=1$ & .5833 \\
\hline \multirow[t]{3}{*}{ Employ $\sim \mathrm{E}$} & overall & 44.31286 & 13.72266 & 4.5 & 93 & & $=$ & 2209 \\
\hline & between & & 15.74951 & 7.188889 & 82.35 & $\mathrm{n}$ & $=$ & 173 \\
\hline & within & & 4.844816 & 5.550356 & 73.15036 & T-bar & $=1$ & .7688 \\
\hline \multirow[t]{3}{*}{ Rural_ T } & overall & 46.92202 & 23.67717 & 0 & 94.584 & N & $=$ & 4884 \\
\hline & between & & 23.50904 & 0 & 91.07212 & & $=$ & 188 \\
\hline & within & & 3.364692 & 30.0231 & 60.54976 & $\mathrm{~T}$ & $:=2$ & .9787 \\
\hline \multirow[t]{3}{*}{ Total_ $\sim R$} & overall & 7.572843 & 11.79362 & 0 & 89.16611 & $\mathrm{~N}$ & $=$ & 4712 \\
\hline & between & & 11.04198 & 0 & 47.18998 & & $=$ & 188 \\
\hline & within & & 4.85076 & -28.56027 & 53.04527 & T-bar & $=2$ & .0638 \\
\hline \multirow[t]{3}{*}{ Popula P } & overall & 192.4447 & 668.4066 & 1.405897 & 7806.773 & & $=$ & 4830 \\
\hline & between & & 662.6799 & 1.612404 & 6385.861 & & $=$ & 187 \\
\hline & within & & 84.15743 & -1457.136 & 1801.679 & T-bar & $=2$ & .8289 \\
\hline \multirow[t]{3}{*}{ Agricu $\sim \mathrm{A}$} & overall & 11048.17 & 18571.08 & 138.7175 & 244495.7 & & $=$ & 4041 \\
\hline & between & & 18202.06 & 242.6211 & 89676.04 & & $=$ & 178 \\
\hline & within & & 7010.074 & -53515.71 & 165867.8 & T-bar & $=2$ & .7022 \\
\hline
\end{tabular}


Appendix B. Testing for random effects: Breusch-Pagan Lagrange multiplier (LM)

xttesto

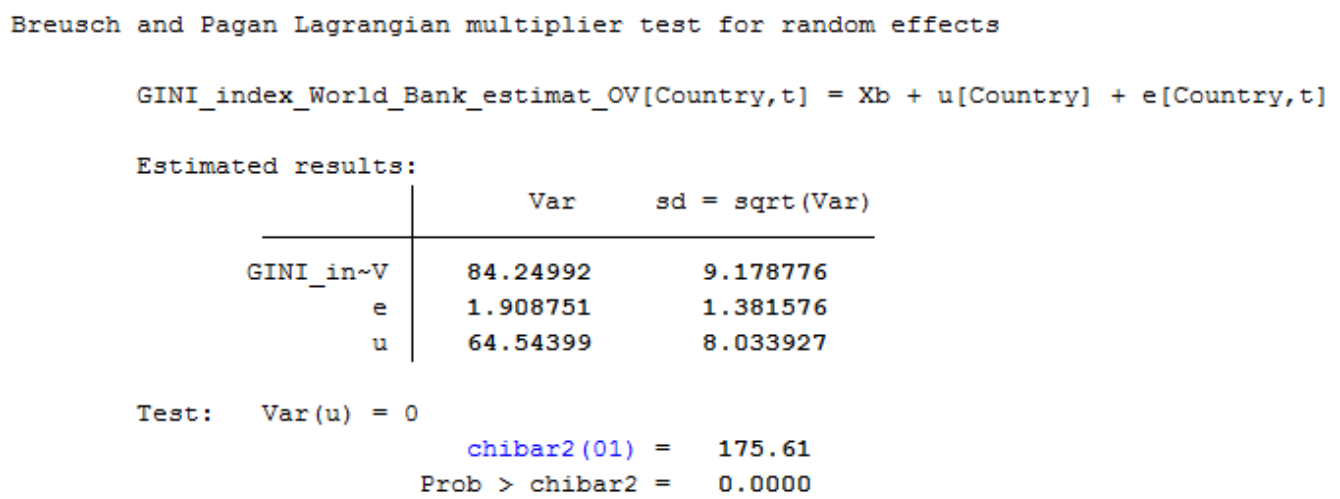

\section{Appendix C. Housman test to choice if using Fixed or Random effect model}

\begin{tabular}{|c|c|c|c|c|}
\hline & \multicolumn{2}{|c|}{ - Coefficients -} & \multirow{3}{*}{$\begin{array}{c}(\mathrm{b}-\mathrm{B}) \\
\text { Difference }\end{array}$} & \multirow{3}{*}{$\begin{array}{c}\left.\operatorname{sqrt}\left(\operatorname{diag}_{\left(\mathrm{V}_{-} b-\mathrm{V}_{-} B\right.}\right)\right) \\
\text { S.E. }\end{array}$} \\
\hline & (b) & (B) & & \\
\hline & fixed & random & & \\
\hline GDP_per_ca A & .0000963 & .0000458 & .0000505 & .0000913 \\
\hline Unemplo LNEZ & .1114296 & .0970201 & .0144095 & .0119909 \\
\hline Inflation_ T & -.0263049 & -.0230109 & -.0032941 & . \\
\hline Health_plū $\sim p$ & -.1911859 & -.1808079 & -.010378 & .0104545 \\
\hline Central_go G & .0137282 & .0147775 & -.0010493 & . \\
\hline Employment $\sim \mathrm{E}$ & -.0121997 & -.0290532 & .0168535 & .0077151 \\
\hline Rural_popu T & .3129971 & .2596126 & .0533846 & .0308185 \\
\hline Total_natu R & .2992508 & .1786336 & .1206172 & .0552729 \\
\hline Population P & -.054715 & -.026022 & -.028693 & .0201844 \\
\hline Agricultur A & .0000421 & .0000321 & .0000101 & .0000114 \\
\hline _cons & 33.50372 & 33.98413 & -.4804108 & 3.565695 \\
\hline
\end{tabular}

$\mathrm{b}=$ consistent under Ho and $\mathrm{Ha}$; obtained from xtreg

$\mathrm{B}=$ inconsistent under $\mathrm{Ha}$, efficient under $\mathrm{Ho}$; obtained from xtreg

Test: Ho: difference in coefficients not systematic

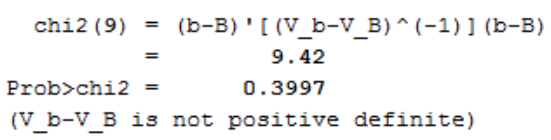

\section{Appendix D. Test of heteroscedasticity}

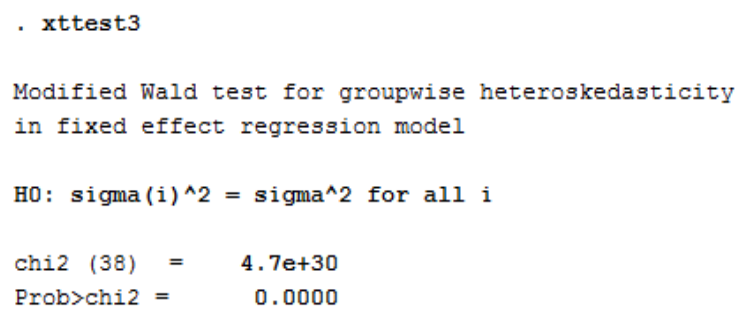




\section{Appendix E. Global model results}

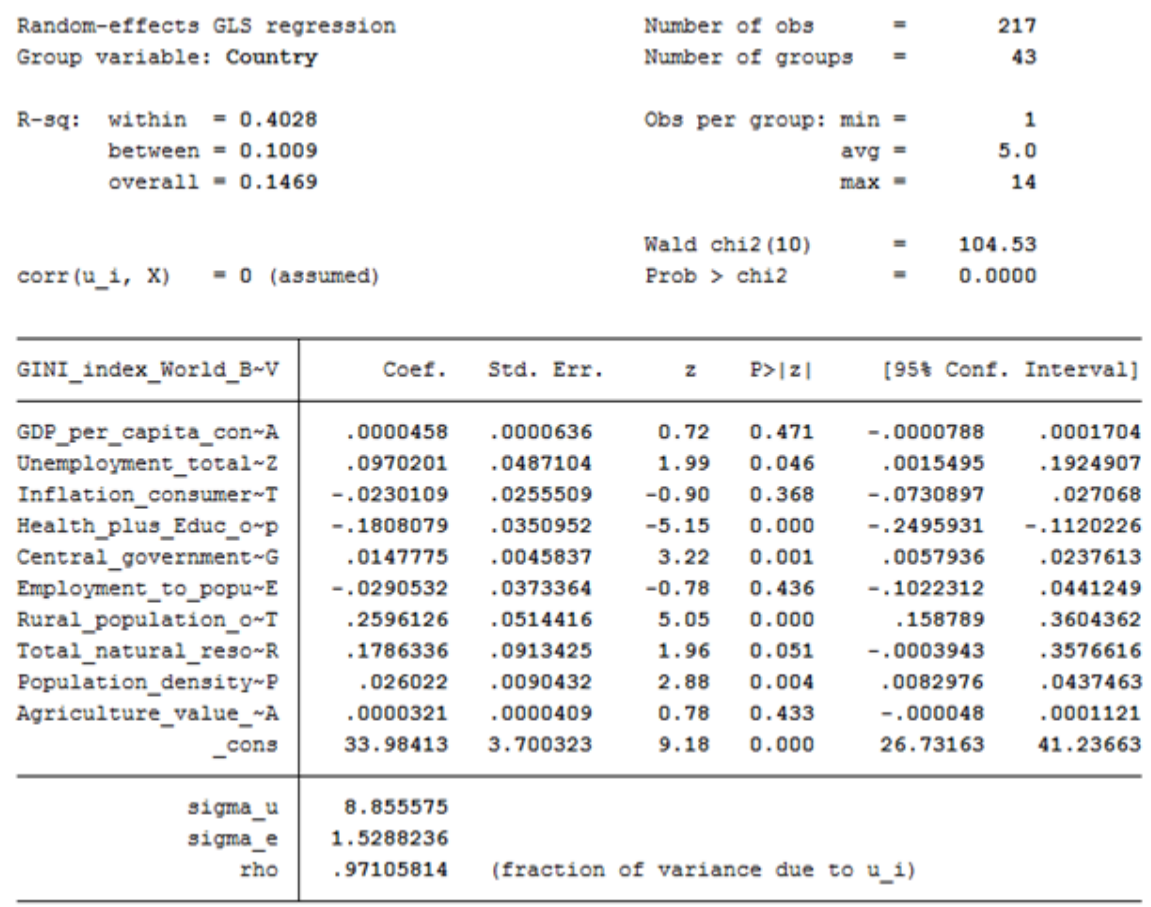

\section{Copyrights}

Copyright for this article is retained by the author(s), with first publication rights granted to the journal.

This is an open-access article distributed under the terms and conditions of the Creative Commons Attribution license (http://creativecommons.org/licenses/by/4.0/). 